Asian-Australasian Journal of

Food Safety and Security

ISSN 2523-1073 (Print) 2523-2983(Online)

https://www.ebupress.com/journal/aajfss/

\title{
Article \\ Proximate analysis and formulation of weaning food using germinated cereals, pulses and ground nut
}

\author{
Most. Masuma Tunazzin Rim ${ }^{1}$, Anusree Ghosh ${ }^{2 *}$, Dr. Anwara Akter Khatun ${ }^{1}$, Most. Rahima Khatun Rima ${ }^{1}$ and \\ Geerja Nath Roy ${ }^{1}$ \\ ${ }^{1}$ Department of Food Science and Nutrition. Hajee Mohammad Danesh Science and Technology University, \\ Dinajpur, Bangladesh \\ ${ }^{2}$ Faculty of Postgraduate Studies, Hajee Mohammad Danesh Science and Technology University, Dinajpur, \\ Bangladesh
}

*Corresponding author: Anusree Ghosh, Faculty of Postgraduate Studies, Hajee Mohammad Danesh Science
and Technology University, Dinajpur-5200, Bangladesh. Phone: +8801749044191; E-mail:
anusreeghosh62@gmail.com

Received: 22 August 2021/Accepted: 08 November 2021/ Published: 30 November 2021

Copyright (C) 2021 Most. Masuma Tunazzin Rim et al. This is an open access article distributed under the Creative Commons Attribution 4.0 International License (https://creativecommons.org/licenses/by/4.0/), which permits unrestricted use, distribution, and reproduction in any medium, provided the original work is properly cited.

\begin{abstract}
A combination of nutritionally inferior diets and improper feeding practices are major contributing factors to the development of childhood malnutrition. Complementary feeding improvement should be of highest priority for nutrition of infant and young children containing all essential nutrients at required amount. The objective of this study was designed to investigate the inclusion of weaning food formulation and evaluating compositional and functional properties of the products. The analysis undertaken in this study was infant food formulation, proximate composition, mineral concentration and sensory properties. The moisture content in this study ranged from $1.49 \pm 0.12$ to $3.89 \pm 0.12$, crude protein from $15.09 \pm 0.05$ to $16.79 \pm 0.01$, crude fat from $11.11 \pm 0.07$ to $12.80 \pm 0.00$, total ash from $2.06 \pm 0.03$ to $2.21 \pm 0.00$, carbohydrate from $65.9740 \pm 0.24$ to $68.2641 \pm 0.14$ and energy value ranged from $431.68 \pm 0.05$ to $449.18 \pm 0.57$. From the result provided, sample-A contained the highest protein, moisture, fat content than sample-B. But carbohydrate and energy are highest in sample-B than sample-A. The two macro minerals $\mathrm{mg} / 100 \mathrm{~g}$ of $\mathrm{Ca}$ and $\mathrm{Zn}$ in the study were ranged from lower $0.60 \pm 0.07$ to $0.79 \pm 0.01$ and $1.05 \pm 0.01$ to $2.44 \pm 0.06$ respectively. Beta-carotene is varied from $0.90 \pm 0.01$ to $1.17 \pm 0.00$. Sensory parameters such as colour, appearance, texture, taste, aroma and overall acceptability is high in sample-A than to sample-B. Finally, from the general trend observed in this study that both the weaning foods prepared from cereal, legume, pulse flour provided better nutritional and functional compositions to meet nutrient dense of infant foods.
\end{abstract}

Keywords: proximate analysis; weaning food; nutrition; bioactive compound; protein energy

\section{Introduction}

Weaning is the transition from exclusive breastfeeding to family foods and it is usually a period between 6 and 18 or 24 months of age, and is a very vulnerable period. It is the time when Protein Energy Malnutrition (PEM) starts in many infants, contributing to the $40 \%$ prevalence of malnutrition in children less than five years of age worldwide (FAO/WHO, 1992). Weaning period is a gradual withdrawal of feeding with the mother's milk and starts feeding it with solid food. The transition from milk to solid or adult food is critical period in the life of a child as weaning practices by the mother profoundly determines child growth and development (Amuna et al., 
2000; Solomon, 2005). Weaning food is semi-solid foods that are used in addition to breast milk and not only replace it. It is prepared in the form of thin porridges. Proper weaning food should supply certain vitamins and minerals not present in breast milk, while providing additional calories. However, with addition of food other than breast milk in the developing countries, there is a marked increase in the danger of gastroenteritis as a potentially fatal disease. This weaning period is a very critical period in the life of a child and if not well managed, might lead to malnutrition and other health implications (Tontisrin et al., 1981; Pedersen et al., 1989; Ozumba et al., 2002).

Epidemiological studies have shown that the prevalence of protein energy malnutrition among the under five years of age children in developing countries is high, due to late weaning, low quality of weaning food and infectious diseases (Pelletier et al., 1993). This is because diets in these areas are predominantly starchy, the major crops being roots, tubers and cereals. This is particularly true among the low-income class who wean their babies on foods high in carbohydrates, such as cocoyam, yam, potato, cassava etc., but low in proteins, vitamins and minerals (Matilda et al., 1993).

A combination of nutritionally inferior diets and improper feeding practices are major contributing factors to the development of childhood malnutrition. Traditional infant foods made of cereals or grains are bulky and may be low in several nutrients including protein, vitamin A, zinc and iron and they also contain high number of factors reducing mineral bioavailability, such as phytates and aflatoxins which is the potential for stunting in children (Suhasini and Malleshi, 2003; Melaku et al., 2005). Complementary feeding improvement should be of highest priority for nutrition of infant and young children containing all essential nutrients at required amount. The concept of improved feeding of infant and young children is not well understood by most families in Ethiopia. The point at which infants begin the actual weaning process i.e., the introduction of grain based solid foods is not the same throughout the country. It varies considerably with the ethnic make-up of the population, the degree of urbanization and the socio-economic status of the families (Ramakrishna et al., 2006). As a result, mothers commonly dilute the porridge with water to reduce its viscosity.

Protein-energy malnutrition generally occurs during the crucial transitional phase when children are weaned from liquid to semi-solid or fully adult foods. During this period, children need nutritionally balanced, caloriedense supplementary foods in addition to mother's milk because of the increasing nutritional demands of the rowing body (Cameroon and Hofvander, 1971; Sajilata et al., 2002). Thus, weaning food plays a vital role in the growth, development and mental health of children. The interventions were carried out to introduce cassava made semisolid diet for weaning children for six months before shifting them to solid diet. Results show complete eradication of malnutrition and control over the diarrhea (Takele, 2009).

Keeping in view of the nutritional importance of weaning food its diversified application, this study was undertaken to develop germinated wheat, rice, pumpkin, carrot, chick pea, mungbean and ground nut based weaning food.

\section{Materials and Methods}

The Weaning Food sample was prepared by combination of various flours such as wheat, rice, ground nut, pumpkin, pumpkin seed, chick pea, mungbean, carrot, milk powder which was made in Food Laboratory of Hajee Mohammad Danesh Science and Technology University and ingredients were purchased from the local market of Dinajpur Town, a secondary town located in the northern Bangladesh.

The Germinated Wheat flour was made out of raw wheat collected from local market. The cleaned wheat was immersed in water of double volume for 24 hours. After 24 hours wheat was separated from water and kept in dark place for proper germination. After germination, germinated wheat was dried at $55^{\circ} \mathrm{C}$ and stopped drying when moisture content was $10-14 \%$. Then the germinated wheat was roasted, ground into powder, and stored at -5 to $-10^{\circ} \mathrm{C}$. The rice was milled and sieved to fine flour. To prepare sweet Pumpkin Powder the raw sweet pumpkin was cleaned properly and peeled. Cut into small pieces and dried at $50^{\circ} \mathrm{C}$. After drying, the pumpkin was ground to fine powder, and stored at -5 to $-10^{\circ} \mathrm{C}$. Pumpkin Seed Powder was prepared by grounded dry seeds. Preparation of Carrot Powder was from small pieces dried at $50^{\circ} \mathrm{C}$. The peeled ground nut was roasted in pan at $120^{\circ} \mathrm{C}$ slightly and cooled at room temperature. After cooling, ground nut was grounded. The Mungbean Flour and Chick Pea Flour were prepared slightly heated beans. The Milk Powder used in the weaning preparation was collected from local market. The study was conducted in samples of the following combination shown in the Table 1. 


\subsection{Proximate analysis of weaning food}

\subsubsection{Determination of moisture content}

AOAC method 7.045 (2000) was used to determine the moisture content, the protein content and Determination of fat of Weaning Food flour.

Moisture content was calculated by following formula:

$\%$ Moisture $=\times 100$

Here, $\mathrm{w}_{1}=$ weight of sample with petridish, $\mathrm{w}_{2}=$ weight of dried sample with petridish, $\mathrm{w}=$ weight of sample

\subsubsection{Determination of protein}

Three stages were used to determine protein content. These stages are given below:

Digestion: Weaning Food flour (1g), Selenium powder (1g), $\mathrm{CuSO}_{4}(0.1 \mathrm{~g}), \mathrm{K}_{2} \mathrm{SO}_{4}(10 \mathrm{~g})$ were taken into a volumetric flask. Then $25 \mathrm{ml}$ of $\mathrm{H}_{2} \mathrm{SO}_{4}$ (conc.) was added. After that the volumetric flask was heated at $100^{\circ} \mathrm{C}$ for 3 hours and cooled for 20 minutes at room temperature.

Distillation: After digestion $300 \mathrm{ml}$ of distilled water and $125 \mathrm{ml}$ of $40 \% \mathrm{NaOH}$ were added to the volumetric flask. $25 \mathrm{ml}$ of $4 \%$ boric acid solution and 2-3 drops mixed indicator was taken into a conical flask. The volumetric flask was connected with one end of the condenser and the conical flask was connected with another end. The volumetric flask was heated continuously until the conical flask was filled to $150 \mathrm{ml}$.

Titration: The conical flask was disconnected and was taken for titration. Titrated against $0.2 \mathrm{~N}$ of $\mathrm{H}_{2} \mathrm{SO}_{4}$ solutions. The end point was indicated by orange colour.

Calculation for N2 content: $\%$ of N2 = Burette reading $\times$ Normality of $\mathrm{H} 2 \mathrm{~S} 04 \times$ ml equivalent of N2, here, Normality of $\mathrm{H} 2 \mathrm{~S} 04=0.2, \mathrm{ml}$ equivalent of $\mathrm{N} 2=1.4$

Calculation for protein content: $\%$ Protein $=\%$ of N2 $\times$ Protein factor; Here, Protein factor $=6.25$

\subsubsection{Determination of fat}

Weaning Food flour $(1 \mathrm{~g})$ was taken into the thimble. The thimble was attached to the Soxhlet apparatus which was attached with a round bottom flask containing $200 \mathrm{ml}$ ether. The fat was extracted for 16 hours. After that ether was evaporated at $80^{\circ} \mathrm{C}$ until the flask completely dried. The difference in the weight of thimble containing the sample before and after extraction was used to calculate the crude fat, as $\%$ Fat $=\times 100$

Here, $\mathrm{W} 1$ = weight of evaporated flask with sample, $\mathrm{W} 2=$ weight of empty flask, $\mathrm{W}=$ weight of sample

\subsubsection{Determination of ash content}

The ash content was determined according to the method reported by Ayesha et al., (2002) with some modification. Weaning Food flour $(5 \mathrm{~g})$ was weighed and transferred into a clean, dry and pre-weighted crucible. Then the crucible was kept into muffle furnace at $550^{\circ} \mathrm{C}$ for 6 hours. It was cooled at desiccator and weighed. The ash content was calculated by the following formula:

$\%$ Ash $=\times 100$

Here, $w_{1}=$ weight of ash with crucible, $w_{2}=$ weight of empty crucible, $w=$ weight of sample

\subsubsection{Preparation of sample for Calcium (Ca) and Zinc $(\mathrm{Zn})$}

$1 \mathrm{~g}$ of sample was taken in a $250 \mathrm{ml}$ conical flask. $10 \mathrm{ml}$ of diacid (nitric acid and $60 \%$ perchloric acid) mixture was added to it. The flask placed in a digestion chamber and heated until dense white fume evolved and the solution became clear. Distilled water was added to the clear residue and mixed thoroughly. The extract (digestion mixture) was then filtered through a Whatman no. 42 filter paper and made up to $100 \mathrm{ml}$ with distilled water. The dilution mixture was then ready for the determination of minerals ( $\mathrm{Ca}$ and $\mathrm{Zn}$ ).

\subsubsection{Determination of Calcium (Ca)}

$10 \mathrm{ml}$ dilution mixture was taken in a conical flask and then $40 \mathrm{ml}$ distilled water was added $2.5 \mathrm{ml}$ of $10 \%$ $\mathrm{NaOH}$ solution was added to the flask. Masking reagent (10 drop potassium ferocyanide, 10 drops hydroxylamine hydrochloride, 10 drops triethnolamine) was added to the flask and 6 drops calcon indicator was added. The flask was shaken vigorously and titrated against $0.01 \mathrm{M}$ of $\mathrm{Na}_{2}$ EDTA. The solution turned to pure blue. A blank was run following the same procedure as above. The data was recorded and the amount of calcium present in the sample was calculated. The percent of calcium was calculated according to the formula: \% Calcium $=40.48 \times 0.01 \times \mathrm{T}$, Where, $40.48 \mathrm{mg}$ calcium $=1 \mathrm{molar} 1 \mathrm{ml}$ EDTA, $0.01=$ Molality of EDTA, $\mathrm{T}=\mathrm{ml}$ EDTA required 
2.1.7. Determination of Zinc (Zn)

$10 \mathrm{ml}$ dilution mixture was taken in a conical flask and then $40 \mathrm{ml}$ distilled water was added $2.5 \mathrm{ml}$ of $10 \%$ $\mathrm{NH}_{4} \mathrm{OH}$ solution was added to the flask. Masking reagent (10 drop potassium ferocyanide, 10 drops hydroxylamine hydrochloride, 10 drops triethnolamine, 10 drops sodium tungsten) was added to the flask and 6 drops EBT indicator was added. The flask was shaken vigorously and titrated against $0.01 \mathrm{M}$ of $\mathrm{Na}_{2} \mathrm{EDTA}_{\mathrm{N}}$. The solution turned to pure blue. A blank was run following the same procedure as above. The data were recorded and the amount of zinc present in the sample was calculated. The percent of calcium was calculated according to the formula: $\%$ zinc $=65.38 \times 0.01 \times \mathrm{T}$, Where, $65.38 \mathrm{mg}$ Zinc $=1 \mathrm{molar} 1 \mathrm{ml}$ EDTA, $0.01=$ Molality of EDTA, $\mathrm{T}=$ ml EDTA required

\subsubsection{Determination of carbohydrate}

Calculated by subtracting the sum of percentage of moisture, fat, protein and ash contents from $100 \%$ according to AOAC (2005):

$$
\text { Carbohydrate }(\%)=100-(\text { moisture } \%+\text { fat } \%+\text { protein } \%+\operatorname{ash} \%)
$$

\subsubsection{Determination of total energy}

The total energy value of the food formulation was calculated according to the method of Mahgoub (1999) using the formula as shown in the following equation: Total energy $(\mathrm{kcal} / 100 \mathrm{~g})=[(\%$ available carbohydrates $\times 4)+(\%$ protein $\times 4)+(\%$ fat $\times 9)]$.

\subsubsection{Determination of Beta-carotene}

Beta-carotene content of Weaning Food sample was determined according to the method of Barros et al. (2007). One gram of sample was mixed with $10 \mathrm{ml}$ of acetone: hexane mixture (4:6) and vortexed for 5 minutes. Then the mixture was filtered through whatman no. 1 and absorbance was measured at $453 \mathrm{~nm}, 505 \mathrm{~nm}$ and $663 \mathrm{~nm}$. Beta-carotene was calculated according to the following equations: Beta-carotene $(\mathrm{mg} / 100 \mathrm{ml})=0.216 \mathrm{~A}_{663}$ $0.304 \mathrm{~A}_{505}+0.452 \mathrm{~A}_{453}$.

\subsubsection{Sensory evaluation}

Sensory evaluation of weaning food formulations was determined on the basis of colour, appearance, texture/consistency, taste, aroma, flavor, mouth feel and overall acceptability using 15 number of semi trained male and female adults who are familiar with the product in question. They were independently evaluated using the difference technique described by Larmond (1977). The nine-point hedonic scale was used to determine the preference of panelist. Rating was done from the range of 1-9 (Table 2). One corresponding with 'dislike extremely' and nine with 'like extremely.'

\subsection{Statistical analysis}

The data were analyzed using the statistical software (SPSS). Analysis of variance was used to find the correlation between the parameters measured and individual effects of the factors were calculated during the study. The tests were indicated significant differences and done at the 5\% level of significance.

\section{Results and Discussion}

\subsection{Proximate analysis of weaning food during storage}

\subsubsection{Moisture content $(\%)$}

The proximate compositions of weaning foods are shown in Table 2 during 0,30 and 60 days of storage. Moisture content of weaning food samples were ranged from 2.29 to $3.89 \%$ and 1.49 to $3.75 \%$ of sample A and B respectively (Figure 1). The values of moisture content of Sample-A and Sample-B were not varied significantly. Moisture content in food sample is an index of stability and determines the appearance, keeping quality and yield of the product (Ejoh et al., 2006).

\subsubsection{Protein content $(\%)$}

The crude protein $(\%)$ in this study was ranged from $16.79 \pm 0.01$ (sample A) to $15.09 \pm 0.05$ (sample B) respectively (Table 1, Figure 2). The crude protein in different weaning formulations differed significantly $(\mathrm{p} \leq 0.05)$. The crude protein in the weaning food formulated in this study was similar to the minimum protein requirement (14\%) of WHO/UN specification for corn-soya bean blend. However, the crude protein (CP) \% of Horlicks from this study was found to be $10.20 \pm 0.00$ which was lower than minimum requirement (14\%) of WHO/UN specification. The crude protein content found in this study was slightly lower than the value reported 
(17.7\%) by Yewelsew et al. (2006) for weaning food processed from selected cereals and legumes but are higher than (7.68 to 8.56) processed from maize-soybean weaning blend reported by Amankwah et al. (2009). Therefore, this study could meet recommended daily allowances (RDA) for protein content (FAO/WHO, 2010).

\subsubsection{Fat content (\%)}

The crude fat $(\%)$ in this study was ranged from $11.11 \pm 0.07$ to $12.80 \pm 0.00$ (Table 1 and Figure 3). However, the crude fat $\%$ of Horlicks $(2.00 \pm 0.00)$ was significantly different $(\mathrm{p} \leq 0.05)$ as compared to sample-A and sample-B. The two products in this study had higher crude fat content than the Horlicks (control) samples. If a diet has a very low-fat content, children may not be able to get adequate amount of energy because of the bulkiness of the diet (Livesey, 1995). Recommended Daily Allowances of fat content for infants and young children has been suggested to be $30-45 \%$ (13.33 to $20.00 \mathrm{~g} / 100 \mathrm{~g}$ ) of energy in the complementary food (WHO/FAO, 2010). The amount of crude fat for homemade weaning foods is less than $10 \mathrm{~g} / 100 \mathrm{~g}$ recommended by WHO (2003) for complementary weaning foods.

\subsubsection{Total ash content $(\%)$}

Total ash content of weaning food formulation in this study varied from $2.06 \pm 0.03$ to $2.21 \pm 0.03$ (Figure 4). According to Mosha et al. (2000) who reported that the ash content in the home-made weaning foods were in the range of $0.83 \mathrm{~g} / 100 \mathrm{~g}$ to $8.37 \mathrm{~g} / 100 \mathrm{~g}$. Ash content is an important nutritional indicator of mineral content and an important quality parameter for contamination, particularly with foreign matters (for example pebbles) (Fennema and Tannenbaum, 1996).

\subsubsection{Total carbohydrate (\%)}

The total carbohydrate content $(\%)$ in two samples ranged from $65.97 \pm 0.24$ to $68.26 \pm 0.14$ and the total carbohydrate content (\%) of Horlicks was obtained 79.80 00.00 . The lowest fat content was obtained from flour sample-A (Figure 5). Although there is no fixed RDA for carbohydrate intake, FAO/WHO (1998) has recommended an intake of about $50 \mathrm{~g}$ per day as being sufficient to meet energy needs for infants. As per Codex Alimentarius Standards, the carbohydrate levels should be 41.13 to $73.79 \mathrm{~g} / 100 \mathrm{~g}$ (FAO/WHO, 1994). Therefore, this study could meet the recommended daily allowances (RDA).

\subsubsection{Total energy content $(\%)$}

The total energy content (\%) in two samples ranged from $431.68 \pm 0.05$ to $449.18 \pm 0.57 \%$ (Table 1, Figure 6) while the total energy content of Horlicks was $378 \pm 0.00$. The lowest fat content was obtained from sample-A. In most developing countries roots, tubers and cereal grains are between the major carbohydrate contributors to the diet. Although there is no fixed RDA for carbohydrate intake, FAO/WHO (1998) has recommended an intake of about $50 \mathrm{~g}$ per day as being sufficient to meet energy needs for infants. In this regard, the two samples could meet this recommendation. The energy content $483.90 \mathrm{Kcal} / 100 \mathrm{~g}$ is the minimum energy recommended in the Codex Alimentarius Standards for weaning/follow up foods (FAO/WHO, 2005). This implies the product would supply the needed energy to meet infant's growth demand.

\subsubsection{Total calcium content $(\%)$}

The calcium $(\mathrm{mg} / 100 \mathrm{~g}$ ) content of test products in this study was ranged from $0.60 \pm 0.07$ to $0.79 \pm 0.01$ (Table 1). The calcium $(\mathrm{mg} / 100 \mathrm{~g}$ ) concentration of Horlicks was found to be $0.741 \pm 0.00$, which was significantly $(p \leq 0.05)$ lower than the weaning food prepared. Other studies on calcium concentration of weaning food processed from legumes are in the range 18.47 to $319.79 \mathrm{mg} / 100 \mathrm{~g}$ for homemade weaning foods as reported by Mosha et al. (2000). The WHO (2013) had also reported the recommended calcium concentration of weaning food to be $400-500 \mathrm{mg} /$ day and none of the weaning food prepared met this demand.

\subsubsection{Total zinc content $(\%)$}

The zinc concentration $(\mathrm{mg} / 100 \mathrm{~g})$ in this study was ranged from $1.05 \pm 0.01$ to $4.44 \pm 0.06$. The zinc $(\mathrm{mg} / 100 \mathrm{~g})$ concentration of the Horlicks was found to be $4.30 \pm 0.00$, which was significantly $(\mathrm{p} \leq 0.05)$ similar to the weaning food. This higher concentration of zinc of the weaning foods prepared from this study might be good plant source of zinc in infant food. Zinc is an important micronutrient for infants and young children since it is used in the synthesis of enzymes, hormones, proteins and other materials that promote optimal physical and mental growth. Zinc also enhances the body's immune system thus, protecting children from infections. Moshat et al. (2000) had reported that the commercial weaning foods contained higher concentrations of zinc as compared to the home-made foods. Zinc concentration of the processed weaning food found in this study was 
higher than the range (2.4-10 $\mathrm{mg} / 100 \mathrm{~g})$ reported by FAO/WHO (2010). Now a day, zinc deficiency affects the health and wellbeing of populations' worldwide and weaning food is one of the few non-animal sources of zinc, its utilization has to be pursued to help in the alleviation of zinc deficiency which is associated to stunting in children.

\subsection{Bioactive compound (beta-carotene) content of weaning food during storage}

The beta-carotene content $(\mathrm{mg} / 100 \mathrm{ml})$ of weaning food prepared from this study had ranged from $0.8690 \pm 0.0092$ to $1.173 \pm 0.0049 \mathrm{mg} / 100 \mathrm{ml}$ (Table 2). The beta-carotene content of Horlicks was $0.741 \pm$ $0.00(\mathrm{mg} / 100 \mathrm{ml})$, which is a very lower value than the weaning food prepared in the present study. For both the Sample A and Sample B the beta-carotene content is higher at one month of storage (Table 3). Infant food prepared by this study could supply adequate requirement of beta-carotene content as similar to suggested by WHO (2003). As reported by FAO/WHO (2010) that the estimated average requirement of beta-carotene content is $0.286 \mathrm{mg} / 100 \mathrm{ml}$ which is lower to the weaning food processed in this study. Other reports showed that RDA of beta carotene content for infants and young children has been suggested is $0.40 \mathrm{mg} / 100 \mathrm{ml}$ (WHO/FAO, 2010).

\subsection{Sensory evaluation}

The sensory quality is an important dimension of the total product quality and is registered by the human senses of sight, smell, taste, touch and hearing (Adenuga, 2010; Lawless and Heyman, 1998). Sensory characteristics of Weaning food formulation are shown in Table 4. The sensory profile of Weaning food was evaluated in terms of colour, appearance, texture, taste, aroma and overall acceptability at 0 day, 30 days and 60 days respectively. The average score given for colour in two samples ranged from $7.33 \pm 0.72$ to $8.11 \pm 0.62$ whereas the colour of Horlicks was ranged from $7.67 \pm 0.62$ to $8.33 \pm 0.48$. The maximum score $(8.47 \pm 0.52)$ for appearance was recorded for Horlicks whereas the maximum appearance score for weaning food was $8.20 \pm 0.56$. The score given for aroma had ranged from $7.47 \pm 0.64$ to $7.80 \pm 0.42$ between Weaning food samples. From this study, the aroma rate of the Horlicks $(8.07 \pm 0.59)$ was a little higher than the aroma of the Weaning food processed. The mean score given for taste on the weaning food processed was ranged from $(6.13 \pm 0.83)$ to $(7.40 \pm 0.74)$ whereas the highest score of colours for Horlicks was $8.13 \pm 0.64$. The taste of the weaning foods improvement might be due to the presence of sugars such as sucrose, fructose, maltose, glucose and raffinose (Kikafunda, 2006). In case of texture, the highest mean score of Weaning food was found to be $7.53 \pm 0.5$. Thus, it was slightly lower acceptability by panellists than Horlicks. The maximum overall acceptability of the weaning food ranged from $7.80 \pm 0.56$ to $7.67 \pm 0.62$ which was nearly similar to the overall acceptability of Horlicks which was ranged from $8.00 \pm 0.52$ to $7.47 \pm 0.52$.

Table 1. Formulation of weaning food sample A and sample $B$.

\begin{tabular}{|l|l|l|l|}
\hline \multicolumn{2}{|l|}{ Weaning Food Sample A } & & \multicolumn{2}{l|}{ Weaning Food Sample B } \\
\hline Name of flour & Amount (gm) & Name of flour & Amount (gm) \\
\hline Germinated Wheat & 30 & Germinated Wheat & 40 \\
\hline Rice & 10 & Chick Pea & 15 \\
\hline Chick Pea & 15 & Mungbean & 10 \\
\hline Mungbean & 10 & Ground Nut & 10 \\
\hline Ground Nut & 10 & Pumkin & 10 \\
\hline Pumpkin & 10 & Pumpkin Seed & 5 \\
\hline Pumpkin Seed & 5 & Carrot & 5 \\
\hline Carrot & 5 & Milk Powder & 5 \\
\hline Milk Powder & 5 & Total & $=100$ \\
\hline Total & $=100$ & & \\
\hline
\end{tabular}


Asian Australas. J. Food Saf. Secur. 2021, 5 (2)

Table 2. Score pattern for sensory evaluation of weaning food.

\begin{tabular}{|l|l|}
\hline Degree of preference & Score \\
\hline Like Extremely & 9 \\
\hline Like Very Much & 8 \\
\hline Like Moderately & 7 \\
\hline Like Slightly & 6 \\
\hline Neither Like or Dislike & 5 \\
\hline Dislike Slightly & 4 \\
\hline Dislike Moderately & 3 \\
\hline Dislike Very Much & 2 \\
\hline Dislike Extremely & 1 \\
\hline
\end{tabular}

Table 3. Beta-carotene content (\%) of weaning food during storage.

\begin{tabular}{|c|c|c|}
\hline Sample & Period of storage & Beta-carotene $(\mathrm{mg} / 100 \mathrm{ml})$ \\
\hline A & $0^{\text {th }}$ day & $0.97 \pm 0.0135$ \\
\hline & $30^{\text {th }}$ day & $1.17 \pm 0.0049$ \\
\hline B & $60^{\text {th }}$ day & $0.90 \pm 0.0$ \\
\hline & $0^{\text {th }}$ day & $0.86 \pm 0.0092$ \\
\hline & $30^{\text {th }}$ day & $1.16 \pm 0.0033$ \\
\hline & $60^{\text {th }}$ day & $0.95 \pm 0.0066$ \\
\hline
\end{tabular}

Table 4. Proximate analysis of weaning food during storage.

\begin{tabular}{|c|c|c|c|c|c|c|c|c|c|}
\hline Sample & $\begin{array}{c}\text { Period of } \\
\text { storage }\end{array}$ & $\begin{array}{c}\text { Quality } \\
\text { parame- } \\
\text { ters }\end{array}$ & & & & & & & \\
\hline & & $\begin{array}{c}\text { Moisture } \\
(\%)\end{array}$ & $\begin{array}{l}\text { Protein } \\
(\%)\end{array}$ & Fat (\%) & $\operatorname{Ash}(\%)$ & $\begin{array}{c}\text { Carbohydrat } \\
\text { e (\%) }\end{array}$ & Energy & $\begin{array}{c}\text { Calcium } \\
(\%)\end{array}$ & Zinc (\%) \\
\hline \multirow{3}{*}{ A } & $0^{\text {th }}$ day & $2.29 \pm 0.08$ & $16.79 \pm 0.01$ & $11.34 \pm 0.12$ & $2.16 \pm 0.02$ & $67.41 \pm 0.04$ & $438.85 \pm 0.84$ & $0.79 \pm 0.01$ & $2.23 \pm 0.04$ \\
\hline & $30^{\text {th }}$ day & $3.49 \pm 0.22$ & $16.62 \pm 0.01$ & $11.81 \pm 0.01$ & $2.10 \pm 0.02$ & $65.97 \pm 0.24$ & $436.67 \pm 0.93$ & $0.72 \pm 0.01$ & $1.05 \pm 0.01$ \\
\hline & $60^{\text {th }}$ day & $3.89 \pm 0.12$ & $15.56 \pm 0.02$ & $11.11 \pm 0.07$ & $2.06 \pm 0.03$ & $67.37 \pm 0.15$ & $431.68 \pm 0.05$ & $0.72 \pm 0.01$ & $1.43 \pm 0.01$ \\
\hline \multirow{3}{*}{ B } & $0^{\text {th }}$ day & $1.49 \pm 0.12$ & $15.23 \pm 0.01$ & $12.80 \pm 0.002$ & $2.21 \pm 0.03$ & $68.26 \pm 0.14$ & $449.18 \pm 0.57$ & $70.64 \pm 0.01$ & $2.44 \pm 0.06$ \\
\hline & $30^{\text {th }}$ day & $3.28 \pm 0.08$ & $15.09 \pm 0.05$ & $12.60 \pm 0.07$ & $2.18 \pm 0.02$ & $66.88 \pm 0.01$ & $441.33 \pm 0.38$ & $0.60 \pm 0.07$ & $1.17 \pm 0.01$ \\
\hline & $60^{\text {th }}$ day & $3.75 \pm 0.04$ & $15.43 \pm 0.04$ & $12.18 \pm 0.02$ & $2.1294 \pm 0.02$ & $66.5137 \pm 0.04$ & $\begin{array}{l}437.4023 \pm 0 . \\
19\end{array}$ & $0.73 \pm 0.01$ & $1.18 \pm 0.01$ \\
\hline Control & & & $10.2 \pm 0.00$ & $2.00 \pm 0.00$ & & $79.80 \pm 0.00$ & $378 \pm 0.00$ & $0.741 \pm 0.00$ & $4.30 \pm 0.00$ \\
\hline
\end{tabular}




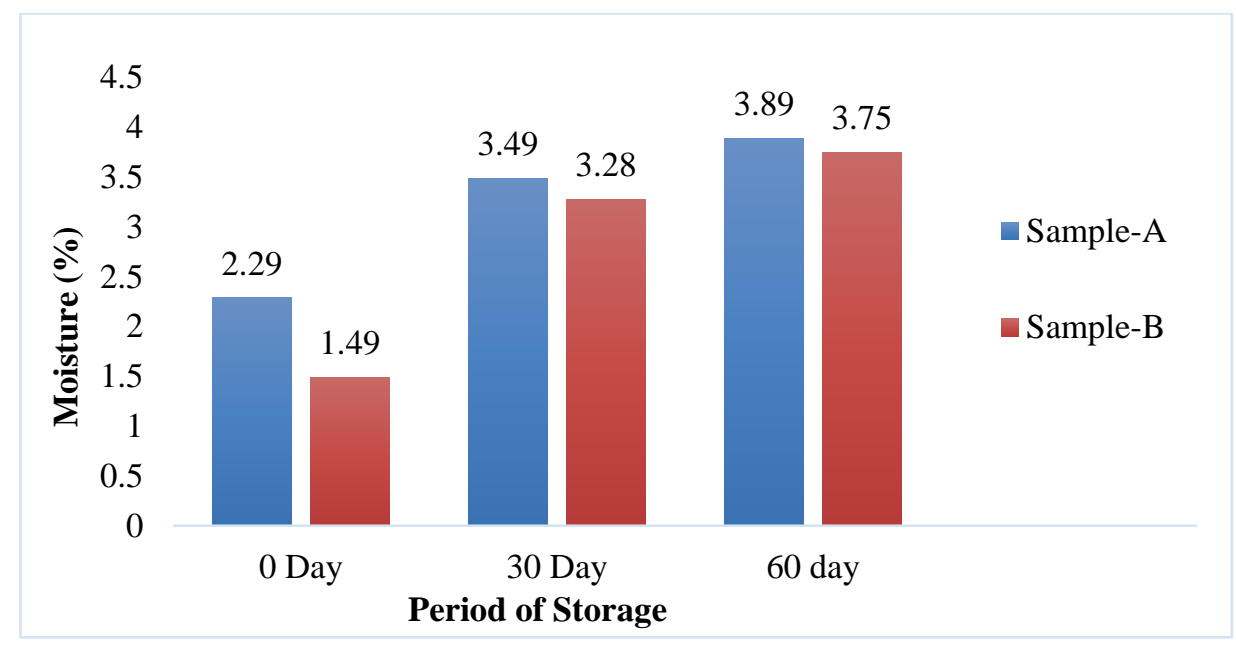

Figure 1. Moisture content (\%) of weaning food formulation during storage.

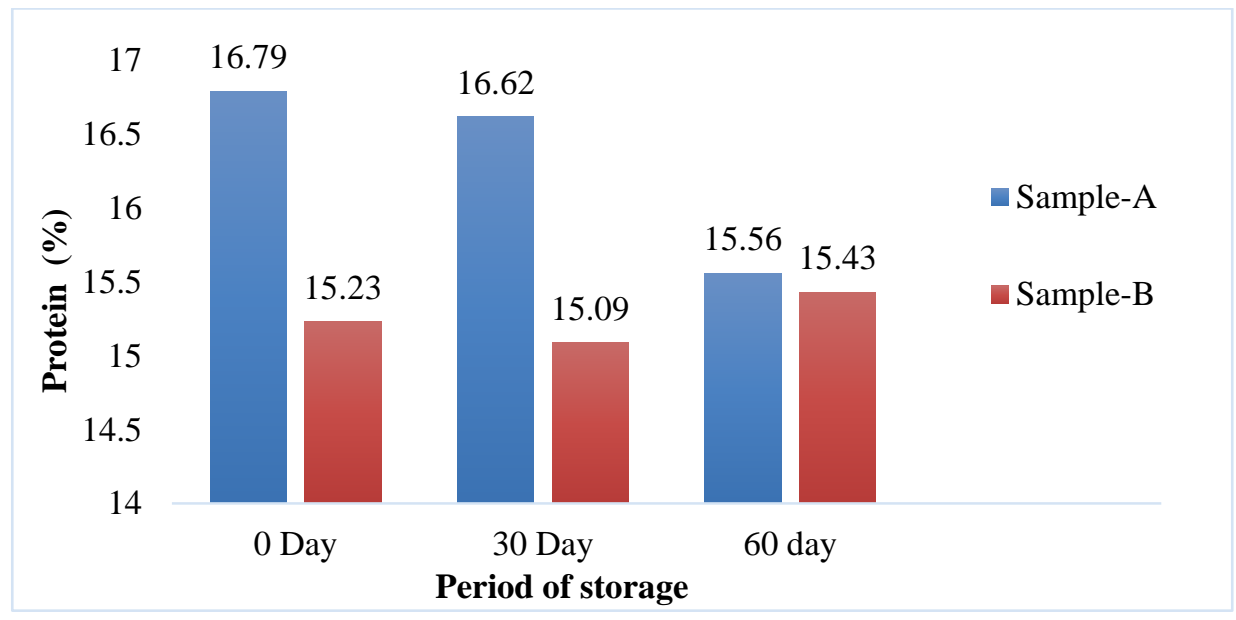

Figure 2. Protein content (\%) of weaning food formulation during storage.

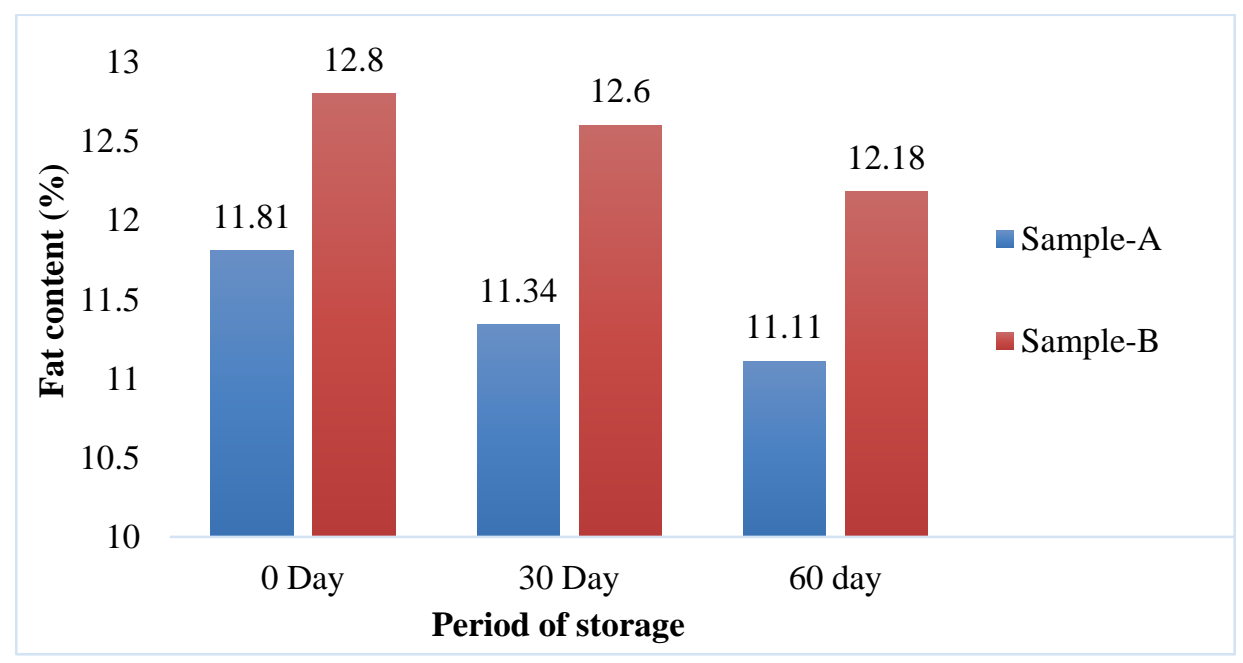

Figure 3. Fat content (\%) of weaning food during storage. 


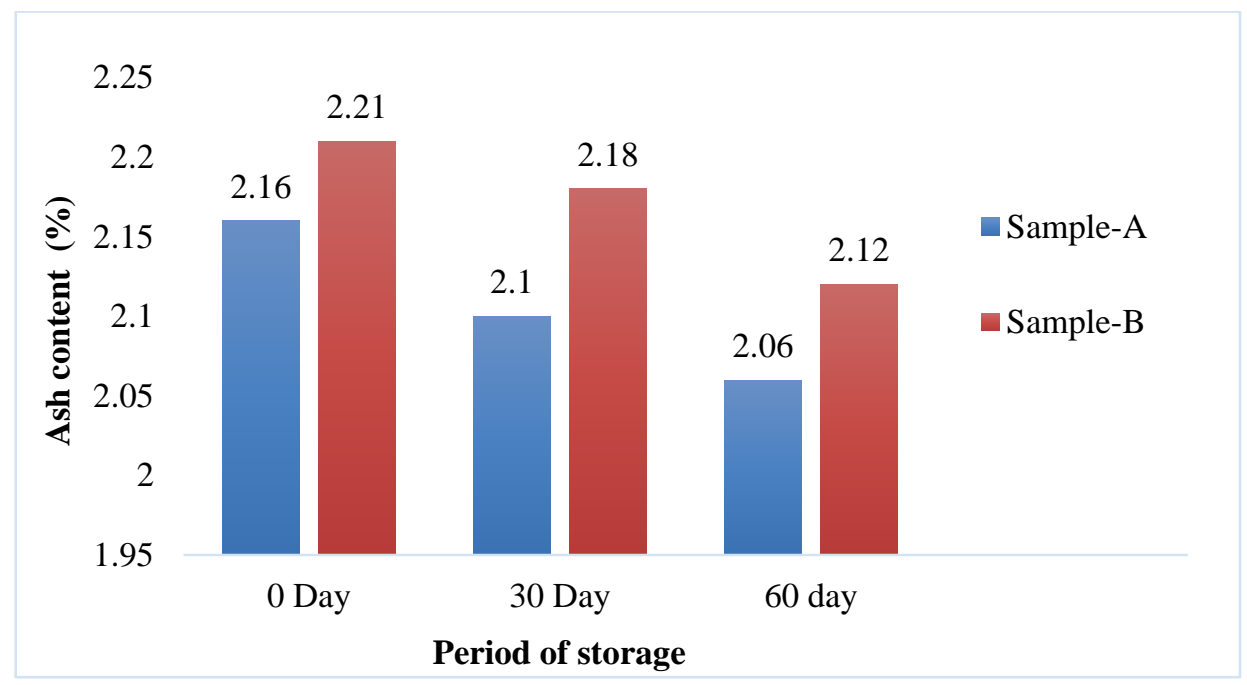

Figure 4. Total ash content (\%) during storage.

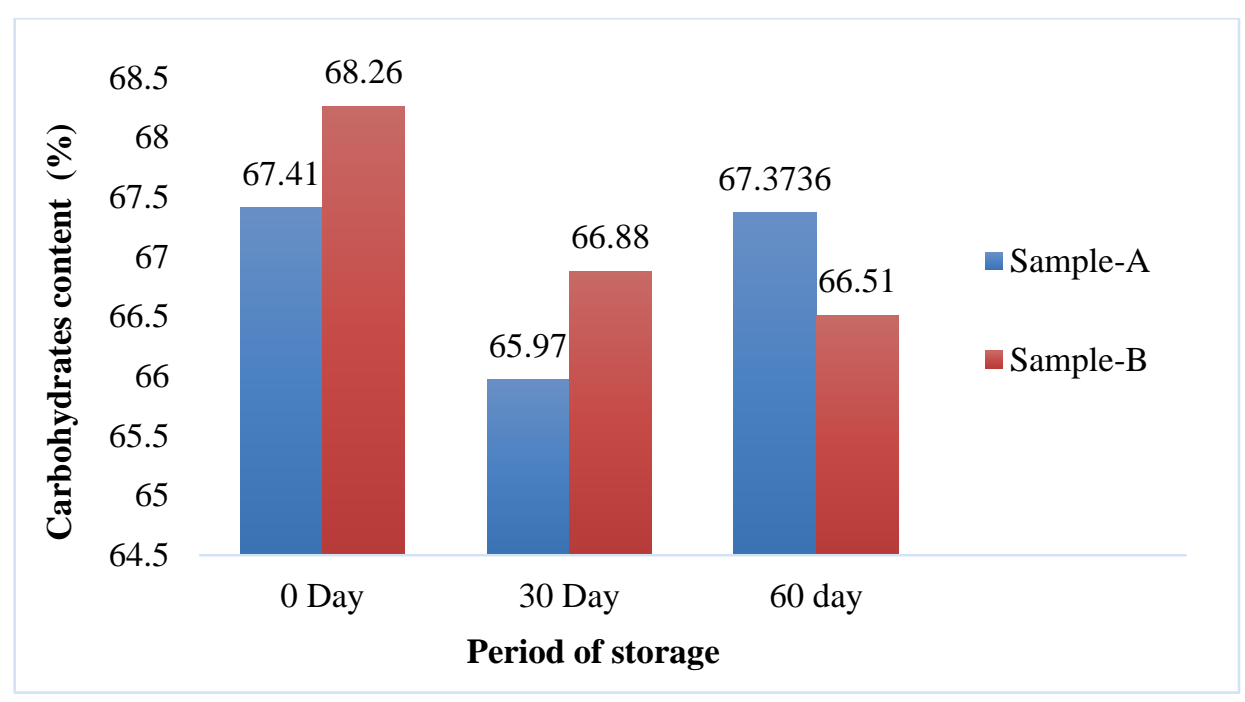

Figure 5. Carbohydrate content of weaning food formulation during storage.

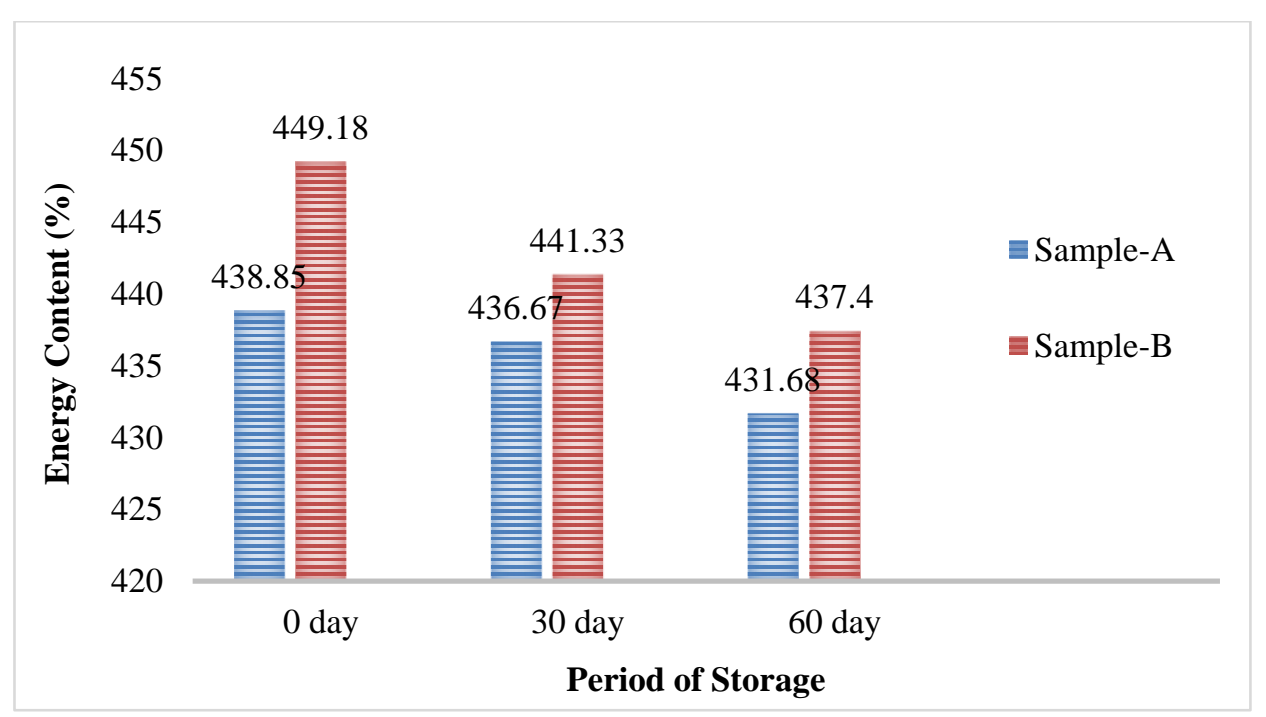

Figure 6. Total energy content $(\%)$ of weaning food. 


\section{Conclusions}

This study showed that formulations of weaning food from germinated wheat, pumpkin, pumpkin seed, carrot, chick pea, mungbean, groundnut, milk powder with or without rice can be produced and stored for a certain period of time. Several proximate analyses of the prepared weaning food samples have taken after one-month intervals. The proximate analysis of moisture, protein, fat, ash, carbohydrates, energy, calcium and zinc in this study show that the weaning food samples are rich in those nutrient constituents. Bioactive compounds (betacarotene) as well as sensory parameters of the prepared weaning food during the storage period will provide an acceptability among the consumers. This will ensure availability and affordability as well as help in alleviating some economic problems that will cause malnutrition, morbidity and mortality in infants in the developing country. At present, the costs of commercial infant foods are very expensive in Bangladesh. Thus, it is believed that this study could give insights for weaning food in industry level for making complementary foods for infants.

\section{Conflict of interest}

None to declare.

\section{Authors' contribution}

MMTR designed the study, performed sample collection, preparation and analysis. MRKR and GNR were assisted in the laboratory works and data collection. AG performed the analysis and developed the writeup along with the review of documents for the discussion. AAK was supervised the whole study and assisted in write-up. MRKR after completion of the study passed away in a traffic accident. All authors have read and approved the final manuscript.

\section{References}

Adenuga W, 2010. Nutritional and sensory profiles of sweet potato based infant weaning food fortified with cowpea and peanut. J. Food Tech., 8: 223-228.

Amankwah EA, J Barimah, R Acheampong, LO Addai and CO Nnaji CO, 2009. Effect of fermentation and malting on the viscosity of maize-soyabean weaning blends, Pakistani J. Nutrition, 8: 1671-1675.

Amuna P, FS Zotor and YR Chinyana, 2006. The role of traditional cereals / legumes / fruit- based multi-mix in weaning in developing countries. J. Food Sci. and Nutrition, 30: 116-122.

AOAC (Association of Official Analytical Chemists), 2000. Official Methods of Analysis of the AOAC international.16thed 4th revised method 944.02. The Association, Gaithersburg, MD.

Ayesha S, N Abid and FM Anjum, 2002. Chemical Composition of Three Wheat (Triticum aestivum L.) Varieties as Affected by NPK Doses. Int. J. Agriculture \& Biology, 4: 537-539.

Barros L, MJ Ferreira, B Queiros, CFR Ferreira and P Baptista, 2007. Total phenols, ascorbic acid, $\beta$-carotene and lycopene in Portuguese wild edible mushrooms and their antioxidant activities. Food Chem., 103: 413419.

Cameroon M and Y Hofvander, 1971. Manual on Feeding Infants and Young Children. P.A.G. Document; 14: 25-26.

Ejoh AR, FT Mbiapo and E Fokou, 2006. Nutrient composition of the leaves and flowers of Colocasia esculenta and the fruits of Solanum melongena. Plant Foods for Human Nutrition, 49: 107-112.

FAO/ WHO, 2010. Codex Committee on Nutrition and Foods for Special Dietary uses. Thirty second Session. Santiago, Chile, 2010. World Health Organization/ Food and Agriculture Organization.

FAO/WHO, 1992. World Declaration and Plan of Action for Nutrition. FAO, Rome, December 1992.

FAO/WHO, 1994. Fats and oils in human nutrition. FAO, Rome.

FAO/WHO, 1998. Preparation and uses of Food-Based Dietary Guidelines: Report of a Joint ood and Agriculture Organisation/World Health Organization Consultation. WHO Technical Report series: 880. Geneva

FAO/WHO, 2005. (World Health Organization) Codex Committee on Nutrition and Foods for Special Dietary uses. Thirty second Session. Santiago, Chile.

FAO/WHO/UNU, 1985. Energy and protein Requirements, WHO Technical series No. 724. World Health Organization, Geneva, Switzerland.

Fennema RO and SR Tannenbaum, 1996. Introduction to Food Chemistry. In: Food Chemistry, Fennema SR, M Karel, GW Sanderson, SR Tannenbaum, P Walstra and JR Witaker (Eds.). Marcel Dekker Inc., New York, pp. 1-64. 
Kikafunda JK, L Abonnatyo and FB Lukluage, 2006. Nutritional and sensory properties of high energy/nutrient dense composite flour porridges from germinated maize and roasted beans for child-weaning in developing countries: a case for Uganda. Ecology of Food and Nutrition, 5: 279-294.

Larmond E, 1977. Laboratory Methods for Sensory Evaluation of Food. Research Branch, Canada Department of Agriculture, Publication No. 1637, 19-63

Lawless HT and H Heyman, 1998. Sensory Evaluation of Food: Principles and Practices. Kluwer Academic/Plenum Publishers, New York, 827.

Livesey G, 1995. Metabolizable energy of macronutrients. American J. Clinical Nutrition, 62:1135S-1142S.

Mahgoub SEO, 1999. Production and evaluation of weaning foods based on sorghum and legumes. Plants Foods Hum Nutr., 54: 29-42.

Matilda A, N Rune, L Oyvind and L Einar, 1993. Effect of Processing (Sprouting and or Fermentation) on Sorghum and Maize.1: Proximate Composition, Minerals and Fatty Acids. Food Chemistry, 46: 351-353.

Melaku U, CE West and H Fikadu, 2005. Content of zinc, iron, calcium and their absorption inhibitors in foods commonly consumed in Ethiopia. J. Food Composition and Analysis, 18: 803-817.

Mosha TCE, HS Laswai and I Tetens, 2003. Nutritional composition and micronutrient status of homemade and commercial weaning foods consumed in Tanzania. Plant Foods for Human Nutrition, 55: 185-205.

Ozumba AU, OO Olatunji and SA Odunfa, 2002. Development and quality evaluation of semi-instant homemade weaning foods. J. Applied Sci., 5: 3124-3138.

Pedersen BH, L Munck and RO Eggun, 1989. Weaning foods with improved energy and nutrient density, prepared from germinated cereals: Nutritional evaluation of gruels based on barley food. Nutrition Bulletin, 11: 46-52.

Pelletier DL, EA Frongillo and J Habicht, 1993. Epidemiologic evidence for a potentiating effect of malnutrition on mortality. American J. Public Health, 83: 1130-3

Ramakrishna V, P Jhanesi Rani and P Ramakrishnarao, 2006. Antinutritional factors during germination in Indian bean (Dolichors lablab L.) seeds. World J. Dairy and Food Sci., 1: 6-11.

Sajilata G, RS Singhal and PR Kulkarni, 2002. Weaning foods: a review of the Indian Experience. Infants Food Nutr. Bull., 23: 208-226.

Solomon M, 2005. Nutritive value of three potential complementary foods based on cereals and legumes. African J. Food and Nutrition Sci., 5: 1-14.

Suhasini AW and NG Malleshi, 2003. Nutritional and carbohydrate characteristics of wheat and chick pea based weaning foods. Int. J. Food Science and Nutrition, 54: 181-187.

Takele, 2009. Monitoring of Malnutrition in Weaning Tribal Infants by introducing banana Made Indigenous Semisolid Diet. Child care in India emerging challenges. Nutrition Foundation of India, New Delhi:13.

Tontisirin K, B Moaleek Dhanamuttas and A Valyasevi, 1981. Formulation of supplementary infant foods at the home and village level in Thailand. Food Nutrition Bulletin, 3: 35-41.

WHO, 2000. Complementary Feeding: Family Foods for Breast Feeding Children. World Health Organisation, Geneva.

WHO, 2003. Feeding and nutrition of infants and young children: guidelines for the WHO European Region with Emphasis on the Former Soviet Countries. WHO Region Publication, European Series, $2003,87$.

WHO, 2013. Global Strategy for Infant and Young Child Feeding, (A54/INF.DOC/4). World Health Organization, Geneva, 2013.

Yewelsew Abebe BJ, MJ Stoeker and GE Hinds Gates, 2006. Nutritional value and sensory acceptability of corn and kocho based food supplemented with legumes for infant feeding in southern Ethiopia. Africa J. Food Agriculture, Nutrition and Dev., 6: 1-19. 